Published in final edited form as:

J Affect Disord. 2015 June 1; 178: 206-214. doi:10.1016/j.jad.2015.03.011.

\title{
Characteristics of Bipolar I Patients Grouped by Externalizing Disorders
}

\author{
Shanker Swaminathan ${ }^{a}$, Daniel L. Kollera, Tatiana Foroud ${ }^{a}$, Howard J. Edenberg ${ }^{a, b}$, \\ Xiaoling Xuei ${ }^{\mathrm{b}}$, Alexander B. Niculescu III ${ }^{\mathrm{c}}$, the Bipolar Genome Study (BiGS) Consortium, \\ and John I. Nurnberger Jr., a,c, ${ }^{*}$ \\ aDepartment of Medical and Molecular Genetics, Indiana University School of Medicine, \\ Indianapolis, Indiana, USA \\ bDepartment of Biochemistry and Molecular Biology, Indiana University School of Medicine, \\ Indianapolis, Indiana, USA \\ CInstitute of Psychiatric Research, Department of Psychiatry, Indiana University School of \\ Medicine, Indianapolis, Indiana, USA
}

\begin{abstract}
Background-Bipolar disorder co-occurs with a number of disorders with externalizing features. The aim of this study is to determine whether Bipolar I (BPI) subjects with comorbid externalizing disorders and a subgroup with externalizing symptoms prior to age 15 have different clinical features than those without externalizing disorders and whether these could be attributed to specific genetic variations.
\end{abstract}

\footnotetext{
(C) 2015 Published by Elsevier B.V.

*Corresponding author: John I. Nurnberger, Jr., Neuroscience Research Building, $320 \mathrm{~W} 15^{\text {th }}$ Street, Suite 200E, Indianapolis, IN 46202-2266, USA, Tel: 317-274-8382; Fax: 317-231-0200; jnurnber@iupui.edu.

Contributors

Shanker Swaminathan contributed to the analysis and interpretation of data for the work; drafting the work, and approval of final article

Daniel L. Koller contributed to the acquisition, analysis and interpretation of data for the work; drafting and critically revising the work, and approval of final article

Tatiana Foroud contributed to the acquisition, analysis and interpretation of data for the work; critically revising the work, and approval of final article

Howard J. Edenberg contributed to the conception and design of the work, acquisition, analysis and interpretation of data for the work; critically revising the work, and approval of final article

Xialong Xuei contributed to the conception and design of the work, acquisition, analysis and interpretation of data for the work; drafting, critically revising the work, and approval of final article

Alexander B. Niculescu, III contributed to the conception and design of the work, acquisition, analysis and interpretation of data for the work; critically revising the work, and approval of final article

The Bipolar Genome Study (BiGS) Consortium contributed to the conception and design of the work, acquisition, analysis and interpretation of data for the work; critically revising the work, and approval of final article

John I Nurnberger, Jr. contributed to the conception and design of the work, acquisition, analysis and interpretation of data for the work; drafting and critically revising the work, and approval of final article
}

\section{Conflict of Interest}

None

Publisher's Disclaimer: This is a PDF file of an unedited manuscript that has been accepted for publication. As a service to our customers we are providing this early version of the manuscript. The manuscript will undergo copyediting, typesetting, and review of the resulting proof before it is published in its final citable form. Please note that during the production process errors may be discovered which could affect the content, and all legal disclaimers that apply to the journal pertain. 
Methods-A large cohort $(\mathrm{N}=2505)$ of Bipolar I subjects was analyzed. Course of illness parameters were compared between an Externalizing Group, an Early-Onset Subgroup and a NonExternalizing group in the Discovery sample $(\mathrm{N}=1268)$. Findings were validated using an independent set of 1237 BPI subjects (Validation sample). Genetic analyses were carried out.

Results-Subjects in the Externalizing Group (and Early-Onset Subgroup) tended to have a more severe clinical course, even in areas specifically related to mood disorder such as cycling frequency and rapid mood switching. Regression analysis showed that the differences are not completely explainable by substance use. Genetic analyses identified nominally associated SNPs; calcium channel genes were not enriched in the gene variants identified.

Limitations-Validation in independent samples is needed to confirm the genetic findings in the present study.

Conclusions-Our findings support the presence of an externalizing disorder subphenotype within BPI with greater severity of mood disorder and possible specific genetic features.

\section{Keywords}

Bipolar disorder; Externalizing disorders; Early onset; Comorbidity; Genome-wide association study (GWAS)

\section{Introduction}

Bipolar disorder (BP) includes distinct episodes with altered mood, activity, and thought patterns. The mean age at onset for Bipolar Disorder Type I (BPI) is 18.4 years and the lifetime prevalence is $0.6 \%$ (Merikangas et al., 2011). BP may occur in conjunction with a number of other disorders such as substance use and anxiety disorders (Merikangas et al., 2011). Substance use has been shown to be highly prevalent in BP patients (Merikangas et al., 2011; Regier et al., 1990). Prior studies have identified more severe outcomes among BP patients with co-occurring substance use disorders (Cardoso et al., 2008; Elizabeth Sublette et al., 2009; Frye and Salloum, 2006; Grunebaum et al., 2006). The presence of substance abuse also makes it more difficult to treat BP (Swann, 2010). The disorder has a substantial genetic component. Monozygotic twin concordance rates range from 45 to $70 \%$ and sibling recurrence risk ranges from 5 to 10\% (Craddock and Forty, 2006). Genome Wide Association Studies (GWAS) have identified ten common variants with modest effects (Chen et al., 2013; Ferreira et al., 2008; Seifuddin et al., 2012; Sklar, 2013; Sklar et al., 2011; Smith et al., 2009; Smith et al., 2011), and analyses using the entire set of variants tested with common GWAS platforms suggest that many additional vulnerability genes remain to be identified as larger samples become available (Cross-Disorder Group of the Psychiatric Genomics et al., 2013; Lee et al., 2011). Many course of illness parameters have also been shown to be heritable (Potash et al., 2007). The aim of this study is to determine whether a subphenotype of BPI subjects can be defined based on the presence of externalizing disorders, and whether these subjects are clinically and/or genetically different from those who did not have externalizing disorders. We were particularly interested in whether the characteristics of the mood disorder itself (apart from externalizing symptoms) differentiated the subgroups. Two sets of BPI subjects ascertained by the National Institute of Mental Health (NIMH) Bipolar Disorder Genetics Initiative and evaluated with the 
Diagnostic Instrument for Genetic Studies (Nurnberger et al., 1994) were included (a Discovery sample and a Validation sample). We also performed GWAS analyses using the combined sample to identify genetic variations that may help characterize these groups.

\section{Methods}

\subsection{Clinical parameters}

BPI subjects were selected from those collected and characterized by the National Institute of Mental Health (NIMH) Bipolar Disorder Genetics Initiative over the past 18 years. Subjects were from Indiana University, Johns Hopkins University, the National Institute of Mental Health Intramural (NIMH) Program, Washington University at St. Louis, University of Pennsylvania, University of California at San Diego, University of California at Irvine, University of California at San Francisco, University of Iowa, University of Chicago, Rush University, and Howard University.

The study protocol was approved by the Institutional Review Board of the respective universities. After description of the study to the subjects, written informed consent was obtained.

2.1.1. Discovery sample-Subjects totaled 951 unrelated European American (EA) individuals and 317 unrelated African-American (AA) individuals. EA status was determined based on the subject's self-report that all four grandparents were of EA heritage. AA status was based on self-report of at least one grandparent being of AA heritage. The 1268 BPI subjects were divided into the following groups: 1) the Non-Externalizing Group-472 subjects; 2) the Externalizing Group-796 subjects who had at least one externalizing disorder and 3) the Early-Onset Subgroup-329 subjects in the Externalizing Group who had two or more symptoms of conduct disorder (CD) prior to age 15 (Table 1). Externalizing disorders included one or more of the following DSM-IV diagnoses: alcohol abuse/dependence, drug abuse/dependence, pathological gambling, anti-social personality disorder (ASPD), attention-deficit hyperactivity disorder (ADHD) and CD (Table 2). Of note, about $70 \%$ of subjects in this sample came from multiplex families (additional affected relatives with BPI disorder).

2.1.2. Validation sample-The validation sample consisted of 1237 unrelated EA BPI subjects from the same study. Based on the above mentioned criteria, these subjects were also divided into 1) the Non-Externalizing Group-436 subjects; 2) the Externalizing Group-801 subjects and 3) the early-onset sub-group-307 subjects (Table 1). Of note, about $20 \%$ of subjects in this sample came from multiplex families.

2.1.3. Clinical assessment-All subjects were interviewed with the Diagnostic Interview for Genetic Studies (DIGS) (Nurnberger et al., 1994), a diagnostic instrument developed for determining mood disorders and related conditions and shown to have excellent test-retest reliability. Final diagnoses were made by two independent clinicians incorporating all available information using a best-estimate procedure. 


\subsection{Genome-wide association analyses}

2.2.1. Genotyping and quality control of data available on dbGaP-Genotyping was carried out at the The Broad Institute Center for Genotyping and Analysis. PicoGreen fluorometry was used to check DNA quantity, and sample quality was initially assessed by genotyping a 24-single nucleotide polymorphism (SNP) panel on the Sequenom iPLEX platform containing a sex determining assay. Samples were plated at 50ng/ul in 96 well plates at the Rutgers University Cell and DNA Repository. The Centre d'Etude du Polymorphisme Human (CEPH; http://www.cephb.fr/en/cephdb/) sample NA12144 was placed on each production plate at the Broad Institute. Genotyping was carried out separately for the EA and AA samples using the Affymetrix Genome-Wide Human SNP Array 6.0. Allele calling was performed using the BirdSeed algorithm Affymetrix Power Tools version apt-1.8.6 and cluster models ('priors') file. Concordance between genotypes from the array and those from the initial quality control (QC) panel was evaluated to confirm sample ID. BPI EA Discovery and Validation samples were pooled together for the GWAS.

Samples were not used in the analysis if they had a low call rate $(<98.5 \%)$ or incompatibility between reported gender and genetically determined gender. Pairwise identity-by-descent estimation was used to check for unexpected familial relationships in PLINK v1.07 (Purcell et al., 2007). SNPs were not analyzed if the minor allele frequency was $<0.01$, call rate $<95 \%$, Hardy Weinberg Equilibrium was violated $\left(P<10^{-6}\right)$ in control samples, if there were three or more Mendelian errors, or if there was more than one discrepancy among duplicate samples. 2064 samples and 677,171 SNPs passed all QC tests. Further information on QC can be obtained in (Smith et al., 2009; Smith et al., 2011).

\subsection{Statistical analyses}

2.3.1. Clinical parameter analyses-Statistical analyses were performed between the Non-Externalizing Group and the Externalizing Group of BPI subjects (including both earlyonset and later-onset subjects), and between the Non-Externalizing Group and the EarlyOnset Subgroup. Categorical variables were analyzed using the Pearson chi-square test (two-sided) and continuous variables were analyzed using an independent samples t-test (two-sided). Levene's Test for Equality of Variances was performed to check the equality of variances assumption. All statistical analyses were performed in SPSS Statistics.

2.3.2. Genetic analyses-All genetic analyses were conducted using PLINK v1.07. The analyses involved testing the association of each SNP coded additively with externalizing and early-onset status, with subject sex included as a covariate in the logistic model employed.

\section{Results}

\subsection{Subject distribution in the non-externalizing and Externalizing Groups}

1268 BPI subjects (951 EA, 317 AA) were included in the Discovery phase of the analysis and the findings were validated using 1237 BPI subjects in the Validation sample (Table 1). The distribution of BPI subjects among the non-externalizing and Externalizing Groups, and the Early-Onset Subgroup was similar for the two samples. 


\subsection{Prevalence of externalizing disorders}

We then examined the distribution of externalizing disorders in the Externalizing Group of BPI subjects in the two studies (Table 2). A majority of subjects had alcohol abuse/ dependence and/or drug abuse/dependence. A higher proportion $(P<0.05)$ of Discovery subjects had drug abuse/dependence and ASPD compared to Validation sample subjects. Conversely, a higher proportion $(P<0.05)$ of Validation sample subjects had ADHD compared to Discovery subjects, but this may be related to assessment methodology (see Discussion). Further information on the breakdown of substance use disorders in the sample cohort can be found in Table S1.

\subsection{Clinical characteristics}

A number of clinical parameters were found to be significantly $(P<0.05)$ different when comparing the Externalizing Group to the Non-Externalizing Group of BPI subjects in the Discovery sample (Tables 3 and 4). Subjects in the Externalizing Group were more likely to be male $\left(\chi^{2}=9.012, d f=1, P=0.003\right)$, to be disabled $\left(\chi^{2}=6.932, d f=1, P=0.008\right)$ and to have fewer years of schooling $(t=6.694, d f=1217, P<0.001)$. They had an earlier age at onset of BPI $(t=7.250, d f=776.393, P<0.001)$ (including earlier onset ages for both depression $(t=5.533, d f=796.274, P<0.001)$ and mania $(t=5.807, d f=837.128, P<0.001)$ ), a higher number of depressive $\left(\chi^{2}=20.902, d f=1, P<0.001\right)$ and manic episodes $\left(\chi^{2}=12.613, d f=1\right.$, $P<0.001$, excluding episodes judged to be secondary to substance use) and a higher frequency of episodes $\left(\chi^{2}=9.763, d f=1, P=0.002 ; \chi^{2}=4.179, d f=1, P=0.041\right)$. The subjects in the Externalizing Group had an increased frequency of incidents of (non-suicidal) self-harm $\left(\chi^{2}=25.797, d f=1, P<0.001\right)$ and more suicide attempts $(t=-2.680, d f=478.609, P=0.008)$. They were rated as more impaired on the interepisode Global Assessment Scale (GAS) $(t=3.771, d f=474, P<0.001)$ and were more likely to report a history of rapid switching $\left(\chi^{2}=21.696, d f=1, P<0.001\right)$ and rapid cycling $\left(\chi^{2}=25.516, d f=1, P<0.001\right)$. We have investigated the effect of ethnicity in externalizing disorders and we find similar results for EA and AA except for disability, frequency of depressive episodes, number and frequency of manic episodes, and age of first tobacco use in case of AA (Tables S2, S3, S4 and S5). The findings in BPI subjects in the overall Discovery sample (Tables 3 and 4) were replicated in BPI subjects in the Validation sample (Tables S6 and S7).

Examination of the clinical variables in the Early-Onset Subgroup shows the same pattern as in the Externalizing Group as a whole, but in general the differences are greater. Nonsuicidal self-harm was seen in $30.2 \%$ of early-onset subjects as compared to $10.0 \%$ of nonexternalizing subjects (and $26.0 \%$ of externalizing subjects as a whole). Rapid switching was seen in $70.6 \%$ of early-onset subjects as compared to $48.6 \%$ of non-externalizing subjects (and $62.8 \%$ of externalizing subjects). Although they are younger, $56.7 \%$ of earlyonset externalizing subjects have had $>8$ non-substance-related depressive episodes in their lifetime compared with $35.5 \%$ of non-externalizing subjects (and $49.5 \%$ of externalizing subjects); $55.1 \%$ have had $>4$ non-substance-related manic episodes in their lifetime compared with $42.8 \%$ of non-externalizing subjects (and $53.5 \%$ of externalizing subjects). They have an earlier age of onset of bipolar disorder by more than 5 years (at 16.0 years compared to 20.4 years) and these ages are similar to the ages of first depressive episode; age of first mania is also advanced by more than 5 years (21.3 years compared to 26.6 
years). Number of suicide attempts is greater (3.6 vs 2.6) and age of first attempt is $>4$ years earlier (20.3 years vs 24.5 years). Patterns are very similar in the Validation sample.

To determine whether the differences in the clinical parameters between subjects in the nonexternalizing and Externalizing Groups can be accounted for by substance use disorders, separate linear regression analyses were performed using frequency of clean depressive episodes/clean manic episodes as the dependent variable, and externalizing disorder status, presence of alcohol abuse/dependence, presence of drug abuse/dependence, ethnicity, presence/absence of first degree relatives with BPI and cohort (years of ascertainment) as independent variables controlling for age and gender in the Discovery sample. The frequency of depressive episodes was found to be a function of externalizing disorder status (standardized $\beta=0.119, P=0.021$ ), but was not completely explained by the presence of alcohol abuse/dependence $(P>0.05)$ or drug abuse/dependence $(P>0.05)$. The frequency of manic episodes was not found to be a function of externalizing disorder status $(P>0.05)$, the presence of alcohol abuse/dependence $(P>0.05)$ or the presence of drug abuse/dependence $(P>0.05)$, but appeared to be related to cohort $(P<0.05)$. This may be related to the preponderance of multiplex families in the earlier cohorts. We further examined the effect of externalizing disorder status controlling for alcohol abuse/dependence in one analysis and drug abuse/dependence in a separate analysis on age at onset of BPI, one of the clinical parameters observed to be significantly different between the non-externalizing and Externalizing Groups. A significant $(P<0.05)$ effect of externalizing disorder status was still observed even when controlling for alcohol and drug use disorders in the two analyses (data not shown). This suggests that other externalizing disorders such as ASPD (Swann et al., 2010), pathological gambling (Kim et al., 2006), ADHD and CD (Masi et al., 2008) may explain a substantial part of the differences seen in the clinical parameters between the externalizing and Non-Externalizing Groups.

\subsection{Genetic association analyses}

Two GWAS analyses were performed comparing: 1) 784 subjects in the Non-Externalizing Group vs. 1280 subjects in the Externalizing Group; 2) 784 subjects in the NonExternalizing Group vs. 502 subjects in the Early-Onset Subgroup. QC was performed on all subjects and all SNPs, as summarized above. Although no SNP reached genome-wide significance $\left(P<5 \times 10^{-8}\right)$ from the two analyses, a number of SNPs were found to be associated at a $P$-value of $10^{-5}$ or lower. Details of 20 SNPs with the strongest association signals from each of the two analyses are shown in Table 5. Since gene variants associated with bipolar disorder have been reported to be enriched for calcium channel genes, we examined that pathway (Cross-Disorder Group of the Psychiatric Genomics, 2013; Sklar et al., 2011) but saw no evidence for enrichment of calcium channel genes in either analysis. We also performed GWAS analyses comparing each of the three groups with the control group, but did not identify any genome-wide significant SNPs in any of these comparisons (data not shown).

\section{Discussion}

The purpose of this study was to determine clinical and genetic differences between BPI subjects who had externalizing disorders and those who did not have externalizing disorders. 
We found that a majority of Discovery and Validation sample BPI subjects had externalizing disorders. We believe that this is the largest cohort of BPI subjects (total $\mathrm{N}=2505$ ) analyzed for factors associated with externalizing symptomatology. Two factors: internalizing and externalizing, appear to substantially account for psychiatric comorbidity among BPI subjects (Monahan et al., in press).

A significant difference in a majority of clinical parameters were found when we compared subjects in the non-externalizing and Externalizing Groups as well as subjects in the NonExternalizing Group and the Early-Onset Subgroup (Tables 3 and 4, online Tables S6 and S7). A possible explanation for the differences seen between these groups is the high proportion of subjects with alcohol abuse/dependence and/or drug abuse/dependence (Table 2). However, our regression studies show that the differences in clinical parameters are not completely explained by the presence or absence of substance use disorders.

The most remarkable result of this study was the increased severity and frequency of mood disorder symptoms and episodes in the Externalizing Group and particularly in the earlyonset externalizing subgroup. In every parameter tested, subjects with externalizing disorders show evidence of greater symptomatology, earlier onset, and more impairment. This is true even when care is taken to exclude the direct effects of substances (e.g. the exclusion of substance-related depressive or manic episodes). In general the chronology suggests that substance use precedes episodes of major mood disorder but it is not clear whether minor mood problems may precede substance use or abuse. In any case, the divisions highlighted in this report appear to be clinically salient.

We noted a higher proportion of subjects in the Validation sample with ADHD compared to the Discovery sample. A section for adult ADHD was included in DIGS 4.0 used for later cohorts but the earlier versions had only a retrospective report of childhood ADHD. Inclusion of the adult ADHD section may be expected to have increased the frequency of ADHD reports (including retrospective childhood ADHD). It is not clear to us how to explain the decrease in ASPD diagnoses and drug abuse/dependence diagnoses in the Validation Sample compared to the Discovery sample. Site effects cannot be ruled out (as the four original sites contributed to a larger proportion of the Discovery sample in comparison to the Validation sample), and such effects have been demonstrated in other studies of bipolar subphenotypes (Saunders et al., 2008). However it is reassuring to note the similarity of the proportions of externalizing and early-onset subjects in the two samples, as well as the very similar results with respect to clinical variables (Tables 3 and 4, Tables S6 and S7).

Although no SNP reached genome-wide significance $\left(P<5 \times 10^{-8}\right)$ in the two GWAS analyses, a number of potential candidate SNPs were found to be nominally associated $\left(P<10^{-5}\right)$ (Table 5). Two intronic SNPs (rs9359856 and rs6934804) and one coding SNP (rs2273238) were identified in the ANKRD6 (ankyrin repeat domain 6) gene on chromosome 6. Also known as Diversin, the gene has been shown to be an essential component of the Wnt-signaling pathway, controlling fusion of heart precursors and gastrulation movements in zebrafish embryogenesis (Moeller et al., 2006; Schwarz-Romond et al., 2002). It has been shown to be prominently expressed in the developing mouse brain suggesting a role during 
brain development and variants in the gene have been associated with muscle performance and habitual physical activity (Tissir et al., 2002; Van Deveire et al., 2012). A SNP in a gene in the same family (ANKRD26) was also noted in this short list. Variants in other identified genes have been associated with fasting glucose-related traits (GLIS3, TMEM195 and ZMAT4) (Dupuis et al., 2010; Meigs et al., 2007) and Alzheimer's disease (MTHFD1L) (Naj et al., 2010). Cerebral glucose metabolic rates are known to be altered in mood disorders (Baxter et al., 1985; Drevets et al., 1997). SNPs in or near ST6GALNAC3, associated with carbohydrate metabolism, are seen three times in this list of 40. Thus, a number of SNPs associated with other diseases/complex traits may play a role in predisposition to externalizing disorders in the presence of bipolar illness. There is no evidence of an enrichment of calcium channel genes, suggesting that this pathway is not likely to explain the difference between externalizing and non-externalizing subtypes of BPI disorder.

The present study includes 2505 unrelated BPI subjects in two samples with clinical and genetic data. Subjects from two different ethnic populations (EA and AA) were analyzed for clinical parameters. However, this is a modest sample size for GWAS analyses and possible significant associations are likely to have been missed. Validation at genome-wide significance levels would be needed to confirm the suggestive associations identified in the present study.

\section{Conclusion}

In sum, we have demonstrated that BPI subjects with externalizing disorders tend to have a poorer clinical outcome then those without externalizing disorders; this is particularly true of those subjects with early onset of conduct disorder symptoms. Although no SNP reached genome-wide significance in the GWAS analyses, it does seem important to us that calcium channel genes do not appear to explain the genetic variance between externalizing and NonExternalizing Groups of BPI subjects. The clinical results in particular suggest the presence of an externalizing disorder subphenotype within BPI warranting further investigation.

\section{Supplementary Material}

Refer to Web version on PubMed Central for supplementary material.

\section{Acknowledgments}

\section{Role of the Funding Source}

This work was supported by grants from the NIMH and NHGRI to the BiGS Consortium (Coordinating Center PI John R Kelsoe) (MH078151, MH081804, MH059567 supplement), and by the Genetic Association Information Network (GAIN). This work was additionally supported by the NIMH Intramural Research Program (Francis J McMahon and Thomas G Schulze). Follow-up genotyping was performed in the laboratory of Howard J Edenberg at Indiana University School of Medicine. This research was also supported, in part, by the Intramural Research Program of the NIH, National Library of Medicine. Data and biomaterials were collected in four projects that participated in the National Institute of Mental Health (NIMH) Bipolar Disorder Genetics Initiative. From 1991 to 1998, the principal investigators and coinvestigators were: Indiana University, Indianapolis, IN, U01 MH46282, John Nurnberger, Marvin Miller and Elizabeth Bowman; Washington University, St Louis, MO, U01 MH46280, Theodore Reich, Allison Goate and John Rice; Johns Hopkins University, Baltimore, MD U01 MH46274, J Raymond DePaulo, Jr, Sylvia Simpson and Colin Stine; NIMH Intramural Research Program, Clinical Neurogenetics Branch, Bethesda, MD, Elliot Gershon, Diane Kazuba and Elizabeth Maxwell. Data and biomaterials were collected as part of 10 projects that participated in the National Institute of Mental Health (NIMH) Bipolar Disorder Genetics Initiative. From 1999 to 2007, the principal investigators and coinvestigators 
were: Indiana University, Indianapolis, IN, R01 MH59545, John Nurnberger, Marvin J Miller, Elizabeth S Bowman, N Leela Rau, P Ryan Moe, Nalini Samavedy, Rif El-Mallakh (at University of Louisville), Husseini Manji (at Wayne State University), Debra A Glitz (at Wayne State University), Eric T Meyer, Carrie Smiley, Tatiana Foroud, Leah Flury, Danielle M Dick, Howard Edenberg; Washington University, St Louis, MO, R01 MH059534, John Rice, Theodore Reich, Allison Goate, Laura Bierut; Johns Hopkins University, Baltimore, MD, R01 MH59533, Melvin McInnis, J Raymond DePaulo, Jr, Dean F MacKinnon, Francis M Mondimore, James B Potash, Peter P Zandi, Dimitrios Avramopoulos and Jennifer Payne; University of Pennsylvania, PA, R01 MH59553, Wade Berrettini; University of California at Irvine, CA, R01 MH60068, William Byerley and Mark Vawter; University of Iowa, IA, R01 MH059548, William Coryell and Raymond Crowe; University of Chicago, IL, R01 MH59535, Elliot Gershon, Judith Badner, Francis McMahon, Chunyu Liu (now at the University of Illinois at Chicago), Alan Sanders, Maria Caserta, Steven Dinwiddie, Tu Nguyen, Donna Harakal; University of California at San Diego, CA, R01 MH59567, John Kelsoe, Rebecca McKinney; Rush University, IL, R01 MH059556, William Scheftner, Howard M Kravitz, Diana Marta, Annette Vaughn-Brown and Laurie Bederow; NIMH Intramural Research Program, Bethesda, MD, 1Z01MH002810-01, Francis J McMahon, Layla Kassem, Sevilla DeteraWadleigh, Lisa Austin, Dennis L Murphy.

The sponsors had no role in the study design; in the collection, analysis and interpretation of data; in the writing of the report; and in the decision to submit the article for publication.

We thank the participants in the study, as without them this work would not have been possible. For best estimate diagnostic work, we thank Vegas Coleman, Robert Schweitzer, N Leela Rau and Kelly Rhoadarmer. For data management, we thank Mariano Erpe and for study coordination Carrie Fisher RN.

\section{References}

Baxter LR Jr, Phelps ME, Mazziotta JC, Schwartz JM, Gerner RH, Selin CE, Sumida RM. Cerebral metabolic rates for glucose in mood disorders. Studies with positron emission tomography and fluorodeoxyglucose F 18. Arch Gen Psychiatry. 1985; 42:441-447. [PubMed: 3872649]

Cardoso BM, Kauer Sant' Anna M, Dias VV, Andreazza AC, Ceresér KM, Kapczinski F. The impact of co-morbid alcohol use disorder in bipolar patients. Alcohol. 2008; 42:451-457. [PubMed: 18760714]

Chen DT, Jiang X, Akula N, Shugart YY, Wendland JR, Steele CJ, Kassem L, Park JH, Chatterjee N, Jamain S, Cheng A, Leboyer M, Muglia P, Schulze TG, Cichon S, Nothen MM, Rietschel M, McMahon FJ, Kelsoe JR, Greenwood TA, Nievergelt CM, McKinney R, Shilling PD, Schork NJ, Smith EN, Bloss CS, Nurnberger JI Jr, Edenberg HJ, Foroud T, Koller DL, Gershon ES, Liu C, Badner JA, Scheftner WA, Lawson WB, Nwulia EA, Hipolito M, Coryell W, Rice J, Byerley W, Berrettini WH, Potash JB, Zandi PP, Mahon PB, McInnis MG, Zollner S, Zhang P, Craig DW, Szelinger S, Barrett TB. Genome-wide association study meta-analysis of European and Asianancestry samples identifies three novel loci associated with bipolar disorder. Mol Psychiatry. 2013; 18:195-205. [PubMed: 22182935]

Craddock N, Forty L. Genetics of affective (mood) disorders. Eur J Hum Genet. 2006; 14:660-668. [PubMed: 16721402]

Cross-Disorder Group of the Psychiatric Genomics C. Identification of risk loci with shared effects on five major psychiatric disorders: a genome-wide analysis. Lancet. 2013; 381:1371-1379. [PubMed: 23453885]

Lee SH, Ripke S, Neale BM, Faraone SV, Purcell SM, Perlis RH, Mowry BJ, Thapar A, Goddard ME, Witte JS, Absher D, Agartz I, Akil H, Amin F, Andreassen OA, Anjorin A, Anney R, Anttila V, Arking DE, Asherson P, Azevedo MH, Backlund L, Badner JA, Bailey AJ, Banaschewski T, Barchas JD, Barnes MR, Barrett TB, Bass N, Battaglia A, Bauer M, Bayes M, Bellivier F, Bergen SE, Berrettini W, Betancur C, Bettecken T, Biederman J, Binder EB, Black DW, Blackwood DH, Bloss CS, Boehnke M, Boomsma DI, Breen G, Breuer R, Bruggeman R, Cormican P, Buccola NG, Buitelaar JK, Bunney WE, Buxbaum JD, Byerley WF, Byrne EM, Caesar S, Cahn W, Cantor RM, Casas M, Chakravarti A, Chambert K, Choudhury K, Cichon S, Cloninger CR, Collier DA, Cook EH, Coon H, Cormand B, Corvin A, Coryell WH, Craig DW, Craig IW, Crosbie J, Cuccaro ML, Curtis D, Czamara D, Datta S, Dawson G, Day R, De Geus EJ, Degenhardt F, Djurovic S, Donohoe GJ, Doyle AE, Duan J, Dudbridge F, Duketis E, Ebstein RP, Edenberg HJ, Elia J, Ennis S, Etain B, Fanous A, Farmer AE, Ferrier IN, Flickinger M, Fombonne E, Foroud T, Frank J, Franke B, Fraser C, Freedman R, Freimer NB, Freitag CM, Friedl M, Frisen L, Gallagher L, Gejman PV, Georgieva L, Gershon ES, Geschwind DH, Giegling I, Gill M, Gordon SD, Gordon-Smith K, Green EK, 
Greenwood TA, Grice DE, Gross M, Grozeva D, Guan W, Gurling H, De Haan L, Haines JL, Hakonarson H, Hallmayer J, Hamilton SP, Hamshere ML, Hansen TF, Hartmann AM, Hautzinger M, Heath AC, Henders AK, Herms S, Hickie IB, Hipolito M, Hoefels S, Holmans PA, Holsboer F, Hoogendijk WJ, Hottenga JJ, Hultman CM, Hus V, Ingason A, Ising M, Jamain S, Jones EG, Jones I, Jones L, Tzeng JY, Kahler AK, Kahn RS, Kandaswamy R, Keller MC, Kennedy JL, Kenny E, Kent L, Kim Y, Kirov GK, Klauck SM, Klei L, Knowles JA, Kohli MA, Koller DL, Konte B, Korszun A, Krabbendam L, Krasucki R, Kuntsi J, Kwan P, Landen M, Langstrom N, Lathrop M, Lawrence J, Lawson WB, Leboyer M, Ledbetter DH, Lee PH, Lencz T, Lesch KP, Levinson DF, Lewis CM, Li J, Lichtenstein P, Lieberman JA, Lin DY, Linszen DH, Liu C, Lohoff FW, Loo SK, Lord C, Lowe JK, Lucae S, MacIntyre DJ, Madden PA, Maestrini E, Magnusson PK, Mahon PB, Maier W, Malhotra AK, Mane SM, Martin CL, Martin NG, Mattheisen M, Matthews K, Mattingsdal M, McCarroll SA, McGhee KA, McGough JJ, McGrath PJ, McGuffin P, McInnis MG, McIntosh A, McKinney R, McLean AW, McMahon FJ, McMahon WM, McQuillin A, Medeiros H, Medland SE, Meier S, Melle I, Meng F, Meyer J, Middeldorp CM, Middleton L, Milanova V, Miranda A, Monaco AP, Montgomery GW, Moran JL, Moreno-De-Luca D, Morken G, Morris DW, Morrow EM, Moskvina V, Muglia P, Muhleisen TW, Muir WJ, Muller-Myhsok B, Murtha M, Myers RM, Myin-Germeys I, Neale MC, Nelson SF, Nievergelt CM, Nikolov I, Nimgaonkar V, Nolen WA, Nothen MM, Nurnberger JI, Nwulia EA, Nyholt DR, O’Dushlaine C, Oades RD, Olincy A, Oliveira G, Olsen L, Ophoff RA, Osby U, Owen MJ, Palotie A, Parr JR, Paterson AD, Pato CN, Pato MT, Penninx BW, Pergadia ML, Pericak-Vance MA, Pickard BS, Pimm J, Piven J, Posthuma D, Potash JB, Poustka F, Propping P, Puri V, Quested DJ, Quinn EM, Ramos-Quiroga JA, Rasmussen HB, Raychaudhuri S, Rehnstrom K, Reif A, Ribases M, Rice JP, Rietschel M, Roeder K, Roeyers H, Rossin L, Rothenberger A, Rouleau G, Ruderfer D, Rujescu D, Sanders AR, Sanders SJ, Santangelo SL, Sergeant JA, Schachar R, Schalling M, Schatzberg AF, Scheftner WA, Schellenberg GD, Scherer SW, Schork NJ, Schulze TG, Schumacher J, Schwarz M, Scolnick E, Scott LJ, Shi J, Shilling PD, Shyn SI, Silverman JM, Slager SL, Smalley SL, Smit JH, Smith EN, Sonuga-Barke EJ, St Clair D, State M, Steffens M, Steinhausen HC, Strauss JS, Strohmaier J, Stroup TS, Sutcliffe JS, Szatmari P, Szelinger S, Thirumalai S, Thompson RC, Todorov AA, Tozzi F, Treutlein J, Uhr M, van den Oord EJ, Van Grootheest G, Van Os J, Vicente AM, Vieland VJ, Vincent JB, Visscher PM, Walsh CA, Wassink TH, Watson SJ, Weissman MM, Werge T, Wienker TF, Wijsman EM, Willemsen G, Williams N, Willsey AJ, Witt SH, Xu W, Young AH, Yu TW, Zammit S, Zandi PP, Zhang P, Zitman FG, Zollner S, Devlin B, Kelsoe JR, Sklar P, Daly MJ, O'Donovan MC, Craddock N, Sullivan PF, Smoller JW, Kendler KS, Wray NR. Cross-Disorder Group of the Psychiatric Genomics C. Genetic relationship between five psychiatric disorders estimated from genome-wide SNPs. Nat Genet. 2013; 45:984-994. [PubMed: 23933821]

Drevets WC, Price JL, Simpson JR Jr, Todd RD, Reich T, Vannier M, Raichle ME. International Inflammatory Bowel Disease Genetics C. Subgenual prefrontal cortex abnormalities in mood disorders. Nature. 1997; 386:824-827. [PubMed: 9126739]

Dupuis J, Langenberg C, Prokopenko I, Saxena R, Soranzo N, Jackson AU, Wheeler E, Glazer NL, Bouatia-Naji N, Gloyn AL, Lindgren CM, Magi R, Morris AP, Randall J, Johnson T, Elliott P, Rybin D, Thorleifsson G, Steinthorsdottir V, Henneman P, Grallert H, Dehghan A, Hottenga JJ, Franklin CS, Navarro P, Song K, Goel A, Perry JRB, Egan JM, Lajunen T, Grarup N, Sparso T, Doney A, Voight BF, Stringham HM, Li M, Kanoni S, Shrader P, Cavalcanti-Proenca C, Kumari M, Qi L, Timpson NJ, Gieger C, Zabena C, Rocheleau G, Ingelsson E, An P, O’Connell J, Luan Ja, Elliott A, McCarroll SA, Payne F, Roccasecca RM, Pattou F, Sethupathy P, Ardlie K, Ariyurek Y, Balkau B, Barter P, Beilby JP, Ben-Shlomo Y, Benediktsson R, Bennett AJ, Bergmann S, Bochud M, Boerwinkle E, Bonnefond A, Bonnycastle LL, Borch-Johnsen K, Bottcher Y, Brunner E, Bumpstead SJ, Charpentier G, Chen Y-DI, Chines P, Clarke R, Coin LJM, Cooper MN, Cornelis M, Crawford G, Crisponi L, Day INM, de Geus EJC, Delplanque J, Dina C, Erdos MR, Fedson AC, Fischer-Rosinsky A, Forouhi NG, Fox CS, Frants R, Franzosi MG, Galan P, Goodarzi MO, Graessler J, Groves CJ, Grundy S, Gwilliam R, Gyllensten U, Hadjadj S, Hallmans G, Hammond N, Han X, Hartikainen A-L, Hassanali N, Hayward C, Heath SC, Hercberg S, Herder C, Hicks AA, Hillman DR, Hingorani AD, Hofman A, Hui J, Hung J, Isomaa B, Johnson PRV, Jorgensen T, Jula A, Kaakinen M, Kaprio J, Kesaniemi YA, Kivimaki M, Knight B, Koskinen S, Kovacs P, Kyvik KO, Lathrop GM, Lawlor DA, Le Bacquer O, Lecoeur C, Li Y, Lyssenko V, Mahley R, Mangino M, Manning AK, Martinez-Larrad MT, McAteer JB, McCulloch LJ, McPherson R, Meisinger C, Melzer D, Meyre D, Mitchell BD, Morken MA, Mukherjee S, Naitza S, Narisu N, Neville MJ, 
Oostra BA, Orru M, Pakyz R, Palmer CNA, Paolisso G, Pattaro C, Pearson D, Peden JF, Pedersen NL, Perola M, Pfeiffer AFH, Pichler I, Polasek O, Posthuma D, Potter SC, Pouta A, Province MA, Psaty BM, Rathmann W, Rayner NW, Rice K, Ripatti S, Rivadeneira F, Roden M, Rolandsson O, Sandbaek A, Sandhu M, Sanna S, Sayer AA, Scheet P, Scott LJ, Seedorf U, Sharp SJ, Shields B, Sigursson G, Sijbrands EJG, Silveira A, Simpson L, Singleton A, Smith NL, Sovio U, Swift A, Syddall H, Syvanen A-C, Tanaka T, Thorand B, Tichet J, Tonjes A, Tuomi T, Uitterlinden AG, van Dijk KW, van Hoek M, Varma D, Visvikis-Siest S, Vitart V, Vogelzangs N, Waeber G, Wagner PJ, Walley A, Walters GB, Ward KL, Watkins H, Weedon MN, Wild SH, Willemsen G, Witteman JCM, Yarnell JWG, Zeggini E, Zelenika D, Zethelius B, Zhai G, Zhao JH, Zillikens MC, Borecki IB, Loos RJF, Meneton P, Magnusson PKE, Nathan DM, Williams GH, Hattersley AT, Silander K, Salomaa V, Smith GD, Bornstein SR, Schwarz P, Spranger J, Karpe F, Shuldiner AR, Cooper C, Dedoussis GV, Serrano-Rios M, Morris AD, Lind L, Palmer LJ, Hu FB, Franks PW, Ebrahim S, Marmot M, Kao WHL, Pankow JS, Sampson MJ, Kuusisto J, Laakso M, Hansen T, Pedersen O, Pramstaller PP, Wichmann HE, Illig T, Rudan I, Wright AF, Stumvoll M, Campbell H, Wilson JF. New genetic loci implicated in fasting glucose homeostasis and their impact on type 2 diabetes risk. Nat Genet. 2010; 42:105-116. [PubMed: 20081858]

Elizabeth Sublette M, Carballo JJ, Moreno C, Galfalvy HC, Brent DA, Birmaher B, John Mann J, Oquendo MA. Substance use disorders and suicide attempts in bipolar subtypes. J Psychiatr Res. 2009; 43:230-238. [PubMed: 18590916]

Ferreira MAR, O'Donovan MC, Meng YA, Jones IR, Ruderfer DM, Jones L, Fan J, Kirov G, Perlis RH, Green EK, Smoller JW, Grozeva D, Stone J, Nikolov I, Chambert K, Hamshere ML, Nimgaonkar VL, Moskvina V, Thase ME, Caesar S, Sachs GS, Franklin J, Gordon-Smith K, Ardlie KG, Gabriel SB, Fraser C, Blumenstiel B, Defelice M, Breen G, Gill M, Morris DW, Elkin A, Muir WJ, McGhee KA, Williamson R, MacIntyre DJ, MacLean AW, St Clair D, Robinson M, Van Beck M, Pereira ACP, Kandaswamy R, McQuillin A, Collier DA, Bass NJ, Young AH, Lawrence J, Nicol Ferrier I, Anjorin A, Farmer A, Curtis D, Scolnick EM, McGuffin P, Daly MJ, Corvin AP, Holmans PA, Blackwood DH, Gurling HM, Owen MJ, Purcell SM, Sklar P, Craddock $\mathrm{N}$. Collaborative genome-wide association analysis supports a role for ANK3 and CACNA1C in bipolar disorder. Nat Genet. 2008; 40:1056-1058. [PubMed: 18711365]

Frye MA, Salloum IM. Bipolar disorder and comorbid alcoholism: prevalence rate and treatment considerations. Bipolar Disorders. 2006; 8:677-685. [PubMed: 17156154]

Grunebaum MF, Galfalvy HC, Nichols CM, Caldeira NA, Sher L, Dervic K, Burke AK, Mann JJ, Oquendo MA. Aggression and substance abuse in bipolar disorder. Bipolar Disorders. 2006; 8:496-502. [PubMed: 17042888]

Kim SW, Grant JE, Eckert ED, Faris PL, Hartman BK. Pathological gambling and mood disorders: Clinical associations and treatment implications. J Affect Disord. 2006; 92:109-116. [PubMed: 16443282]

Lee SH, Wray NR, Goddard ME, Visscher PM. Estimating missing heritability for disease from genome-wide association studies. Am J Hum Genet. 2011; 88:294-305. [PubMed: 21376301]

Masi G, Milone A, Manfredi A, Pari C, Paziente A, Millepiedi S. Comorbidity of conduct disorder and bipolar disorder in clinically referred children and adolescents. J Child Adolesc Psychopharmacol. 2008; 18:271-279. [PubMed: 18582182]

Meigs J, Manning A, Fox C, Florez J, Liu C, Cupples LA, Dupuis J. Genome-wide association with diabetes-related traits in the Framingham Heart Study. BMC Medical Genetics. 2007; 8:S16. [PubMed: 17903298]

Merikangas KR, Jin R, He JP, Kessler RC, Lee S, Sampson NA, Viana MC, Andrade LH, Hu C, Karam EG, Ladea M, Medina-Mora ME, Ono Y, Posada-Villa J, Sagar R, Wells JE, Zarkov Z. Prevalence and correlates of bipolar spectrum disorder in the world mental health survey initiative. Arch Gen Psychiatry. 2011; 68:241-251. [PubMed: 21383262]

Moeller H, Jenny A, Schaeffer HJ, Schwarz-Romond T, Mlodzik M, Hammerschmidt M, Birchmeier W. Diversin regulates heart formation and gastrulation movements in development. Proc Natl Acad Sci USA. 2006; 103:15900-15905. [PubMed: 17032765]

Monahan PO, Stump T, Coryell WH, Harezlak J, Marcoulides GA, Liu H, Steeger CM, Mitchell P, Wilcox H, Hulvershorn L, Glowinski AL, Nurnberger JI Jr. Bipolar Disorder Genome Study 
(BiGS) Consortium Bipolar High Risk Study Group . Confirmatory test of two factors and four subtypes of bipolar disorder based on lifetime psychiatric comorbidity. Psychol Med. in press.

Naj AC, Beecham GW, Martin ER, Gallins PJ, Powell EH, Konidari I, Whitehead PL, Cai G, Haroutunian V, Scott WK, Vance JM, Slifer MA, Gwirtsman HE, Gilbert JR, Haines JL, Buxbaum JD, Pericak-Vance MA. Dementia Revealed: Novel Chromosome 6 Locus for LateOnset Alzheimer Disease Provides Genetic Evidence for Folate-Pathway Abnormalities. PLoS Genet. 2010; 6:e1001130. [PubMed: 20885792]

Nurnberger JI Jr, Blehar MC, Kaufmann CA, York-Cooler C, Simpson SG, Harkavy-Friedman J, Severe JB, Malaspina D, Reich T. Diagnostic Interview for Genetic Studies: Rationale, Unique Features, and Training. Arch Gen Psychiatry. 1994; 51:849-859. [PubMed: 7944874]

Potash JB, Toolan J, Steele J, Miller EB, Pearl J, Zandi PP, Schulze TG, Kassem L, Simpson SG, Lopez V, MacKinnon DF, McMahon FJ. NIMH Genetics Initiative Bipolar Disorder Consortium. The Bipolar Disorder Phenome Database: A Resource for Genetic Studies. Am J Psychiatry. 2007; 164:1229-1237. [PubMed: 17671286]

Purcell S, Neale B, Todd-Brown K, Thomas L, Ferreira MAR, Bender D, Maller J, Sklar P, de Bakker PIW, Daly MJ, Sham PC. PLINK: A Tool Set for Whole-Genome Association and PopulationBased Linkage Analyses. Am J Hum Genet. 2007; 81:559-575. [PubMed: 17701901]

Regier DA, Farmer ME, Rae DS, Locke BZ, Keith SJ, Judd LL, Goodwin FK. Comorbidity of Mental Disorders With Alcohol and Other Drug Abuse. JAMA: The Journal of the American Medical Association. 1990; 264:2511-2518.

Saunders EH, Scott LJ, McInnis MG, Burmeister M. Familiality and diagnostic patterns of subphenotypes in the National Institutes of Mental Health bipolar sample. Am J Med Genet B Neuropsychiatr Genet. 2008; 147B:18-26. [PubMed: 17525972]

Schwarz-Romond T, Asbrand C, Bakkers J, Kühl M, Schaeffer H-J, Huelsken J, Behrens J, Hammerschmidt M, Birchmeier W. The ankyrin repeat protein Diversin recruits Casein kinase I $\varepsilon$ to the $\beta$-catenin degradation complex and acts in both canonical Wnt and Wnt/JNK signaling. Genes Dev. 2002; 16:2073-2084. [PubMed: 12183362]

Seifuddin F, Mahon PB, Judy J, Pirooznia M, Jancic D, Taylor J, Goes FS, Potash JB, Zandi PP. Metaanalysis of genetic association studies on bipolar disorder. Am J Med Genet B Neuropsychiatr Genet. 2012; 159B:508-518. [PubMed: 22573399]

Sklar, P. Analysis of 48,000 Psychiatric Genomic Consortium (PGC) Bipolar Case-control Samples. XXIst World Congress Of Psychiatric Genetics; Boston, Massachusetts. 2013.

Sklar P, Ripke S, Scott LJ, Andreassen OA, Cichon S, Craddock N, Edenberg HJ, Nurnberger JI Jr, Rietschel M, Blackwood D, Corvin A, Flickinger M, Guan W, Mattingsdal M, McQuillin A, Kwan P, Wienker TF, Daly M, Dudbridge F, Holmans PA, Lin D, Burmeister M, Greenwood TA, Hamshere ML, Muglia P, Smith EN, Zandi PP, Nievergelt CM, McKinney R, Shilling PD, Schork NJ, Bloss CS, Foroud T, Koller DL, Gershon ES, Liu C, Badner JA, Scheftner WA, Lawson WB, Nwulia EA, Hipolito M, Coryell W, Rice J, Byerley W, McMahon FJ, Schulze TG, Berrettini W, Lohoff FW, Potash JB, Mahon PB, McInnis MG, Zollner S, Zhang P, Craig DW, Szelinger S, Barrett TB, Breuer R, Meier S, Strohmaier J, Witt SH, Tozzi F, Farmer A, McGuffin P, Strauss J, Xu W, Kennedy JL, Vincent JB, Matthews K, Day R, Ferreira MA, O’Dushlaine C, Perlis R, Raychaudhuri S, Ruderfer D, Hyoun PL, Smoller JW, Li J, Absher D, Thompson RC, Meng FG, Schatzberg AF, Bunney WE, Barchas JD, Jones EG, Watson SJ, Myers RM, Akil H, Boehnke M, Chambert K, Moran J, Scolnick E, Djurovic S, Melle I, Morken G, Gill M, Morris D, Quinn E, Muhleisen TW, Degenhardt FA, Mattheisen M, Schumacher J, Maier W, Steffens M, Propping P, Nothen MM, Anjorin A, Bass N, Gurling H, Kandaswamy R, Lawrence J, McGhee K, McIntosh A, McLean AW, Muir WJ, Pickard BS, Breen G, St Clair D, Caesar S, Gordon-Smith K, Jones L, Fraser C, Green EK, Grozeva D, Jones IR, Kirov G, Moskvina V, Nikolov I, O’Donovan MC, Owen MJ, Collier DA, Elkin A, Williamson R, Young AH, Ferrier IN, Stefansson K, Stefansson H, Thornorgeirsson T, Steinberg S, Gustafsson O, Bergen SE, Nimgaonkar V, Hultman C, Landen M, Lichtenstein P, Sullivan P, Schalling M, Osby U, Backlund L, Frisen L, Langstrom N, Jamain S, Leboyer M, Etain B, Bellivier F, Petursson H, Sigur Sson E, Muller-Mysok B, Lucae S, Schwarz M, Schofield PR, Martin N, Montgomery GW, Lathrop M, Oskarsson H, Bauer M, Wright A, Mitchell PB, Hautzinger M, Reif A, Kelsoe JR, Purcell SM. Large-scale genome-wide association analysis of bipolar disorder identifies a new susceptibility locus near ODZ4. Nat Genet. 2011; 43:977-983. [PubMed: 21926972] 
Smith EN, Bloss CS, Badner JA, Barrett T, Belmonte PL, Berrettini W, Byerley W, Coryell W, Craig D, Edenberg HJ, Eskin E, Foroud T, Gershon E, Greenwood TA, Hipolito M, Koller DL, Lawson WB, Liu C, Lohoff F, McInnis MG, McMahon FJ, Mirel DB, Murray SS, Nievergelt C, Nurnberger J, Nwulia EA, Paschall J, Potash JB, Rice J, Schulze TG, Scheftner W, Panganiban C, Zaitlen N, Zandi PP, Zollner S, Schork NJ, Kelsoe JR. Genome-wide association study of bipolar disorder in European American and African American individuals. Mol Psychiatry. 2009; 14:755763. [PubMed: 19488044]

Smith EN, Koller DL, Panganiban C, Szelinger S, Zhang P, Badner JA, Barrett TB, Berrettini WH, Bloss CS, Byerley W, Coryell W, Edenberg HJ, Foroud T, Gershon ES, Greenwood TA, Guo Y, Hipolito M, Keating BJ, Lawson WB, Liu C, Mahon PB, McInnis MG, McMahon FJ, McKinney R, Murray SS, Nievergelt CM, Nurnberger JI Jr, Nwulia EA, Potash JB, Rice J, Schulze TG, Scheftner WA, Shilling PD, Zandi PP, Zollner S, Craig DW, Schork NJ, Kelsoe JR. Genome-wide association of bipolar disorder suggests an enrichment of replicable associations in regions near genes. PLoS Genet. 2011; 7:e1002134. [PubMed: 21738484]

Swann AC. The strong relationship between bipolar and substance-use disorder. Ann N Y Acad Sci. 2010; 1187:276-293. [PubMed: 20201858]

Swann AC, Lijffijt M, Lane SD, Steinberg JL, Moeller FG. Interactions between bipolar disorder and antisocial personality disorder in trait impulsivity and severity of illness. Acta Psychiatr Scand. 2010; 121:453-461. [PubMed: 20064125]

Tissir F, Bar I, Goffinet AM, Lambert De Rouvroit C. Expression of the ankyrin repeat domain 6 gene (Ankrd6) during mouse brain development. Dev Dyn. 2002; 224:465-469. [PubMed: 12203740]

Van Deveire KN, Scranton SK, Kostek MA, Angelopoulos TJ, Clarkson PM, Gordon PM, Moyna NM, Visich PS, Zoeller RF, Thompson PD, Devaney JM, Gordish-Dressman H, Hoffman EP, Maresh CM, Pescatello LS. Variants of the ankyrin repeat domain 6 gene (ANKRD6) and muscle and physical activity phenotypes among European-derived American adults. J Strength Cond Res. 2012; 26:1740-1748. [PubMed: 22580979]

\section{The Bipolar Genome Study (BiGS) Consortium members}

University of California, San Diego: John R. Kelsoe, Tiffany A. Greenwood, Caroline M. Nievergelt, Rebecca McKinney, Paul D. Shilling

Scripps Translational Science Institute: Nicholas J. Schork, Erin N. Smith, Cinnamon S. Bloss

Indiana University: John I. Nurnberger, Jr., Howard J. Edenberg, Tatiana Foroud, Daniel L. Koller

University of Chicago: Elliot S. Gershon, Chunyu Liu, Judith A. Badner

Rush University Medical Center: William A. Scheftner

Howard University: William B. Lawson, Evaristus A. Nwulia, Maria Hipolito

University of Iowa: William Coryell

Washington University: John Rice

University of California, San Francisco: William Byerley

NIMH: Francis J. McMahon, Thomas G. Schulze

University of Pennsylvania: Wade H. Berrettini 
John Hopkins: James B. Potash, Peter P. Zandi, Pamela B. Mahon

University of Michigan: Melvin G. McInnis, Sebastian Zollner, Peng Zhang

The Translational Genomics Research Institute: David W. Craig, Szabolcs Szelinger

Portland Veterans Affairs Medical Center: Thomas B. Barrett

Georg-August-University Gottingen: Thomas G. Schulze 


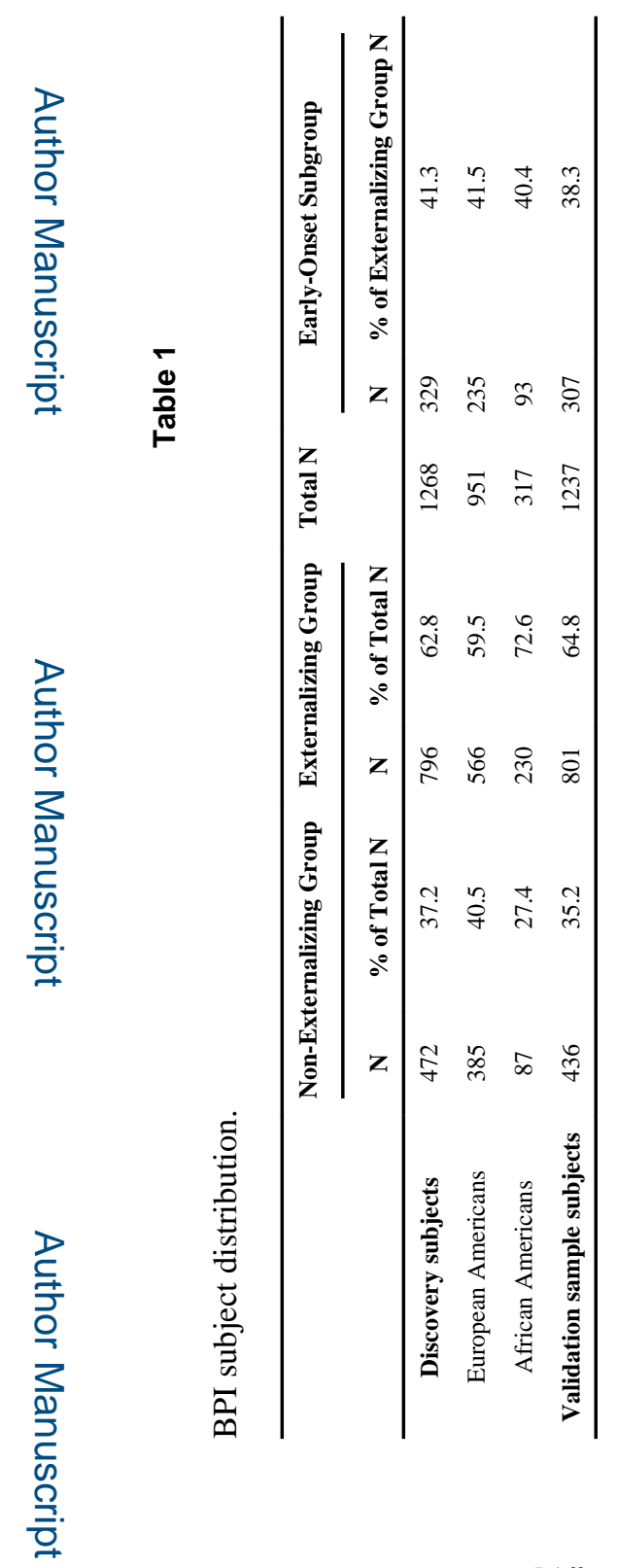

J Affect Disord. Author manuscript; available in PMC 2016 June 01. 

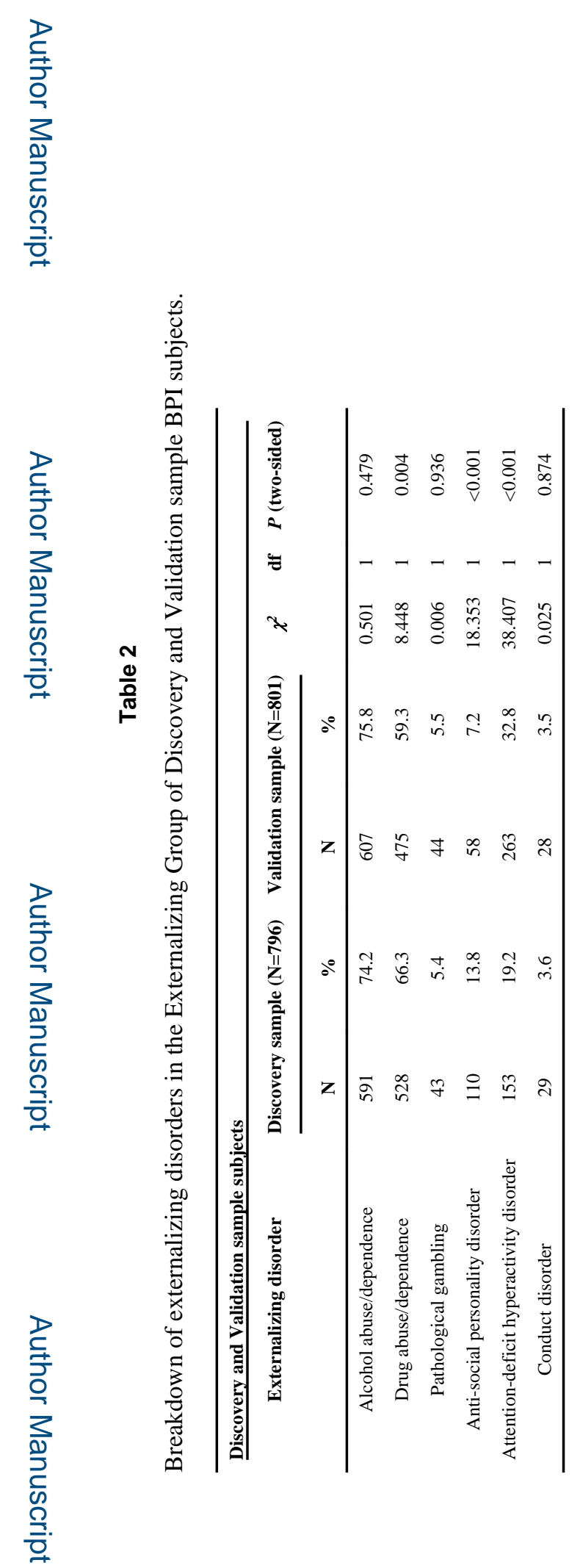

J Affect Disord. Author manuscript; available in PMC 2016 June 01. 


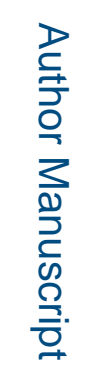

굴

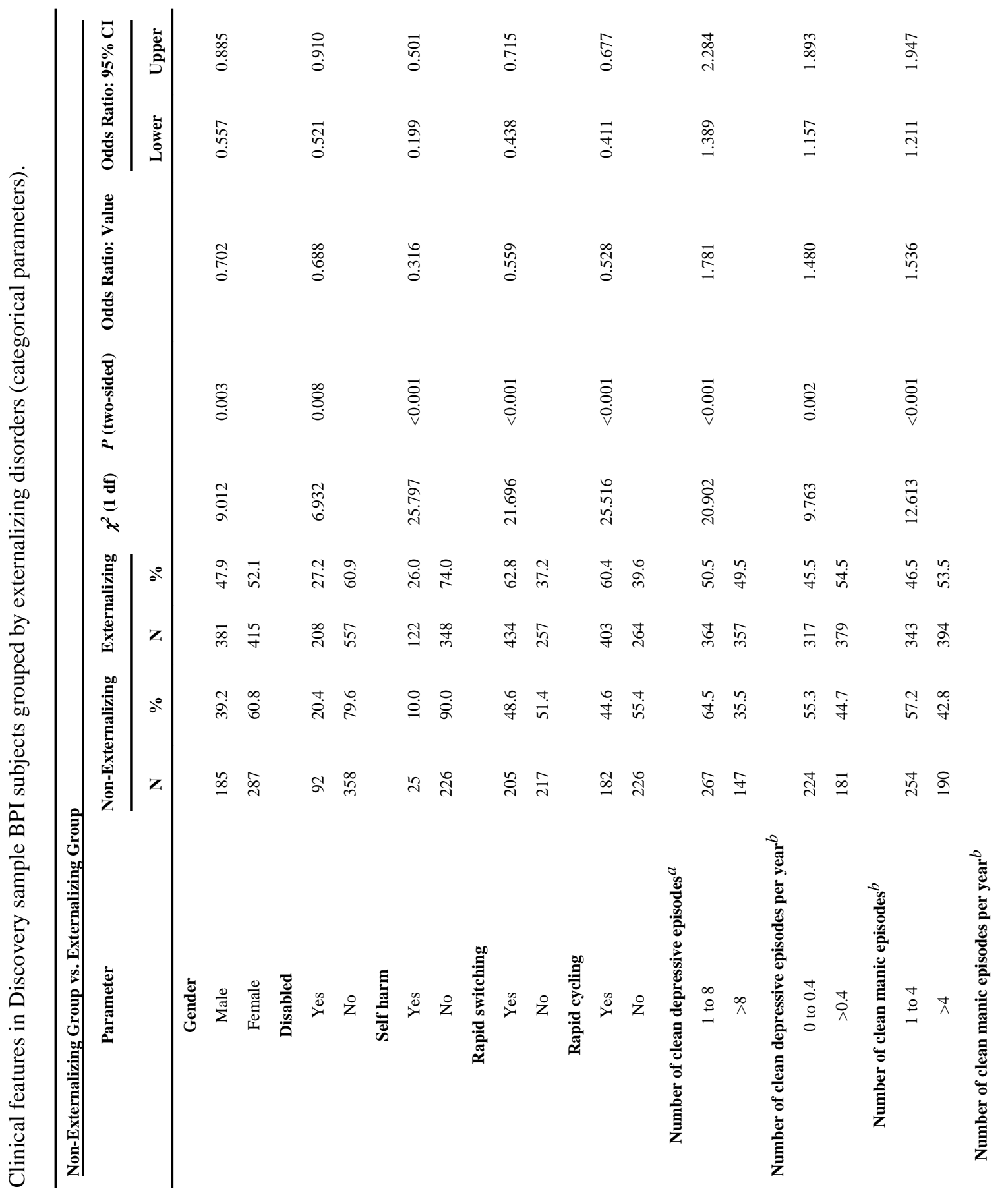

J Affect Disord. Author manuscript; available in PMC 2016 June 01. 

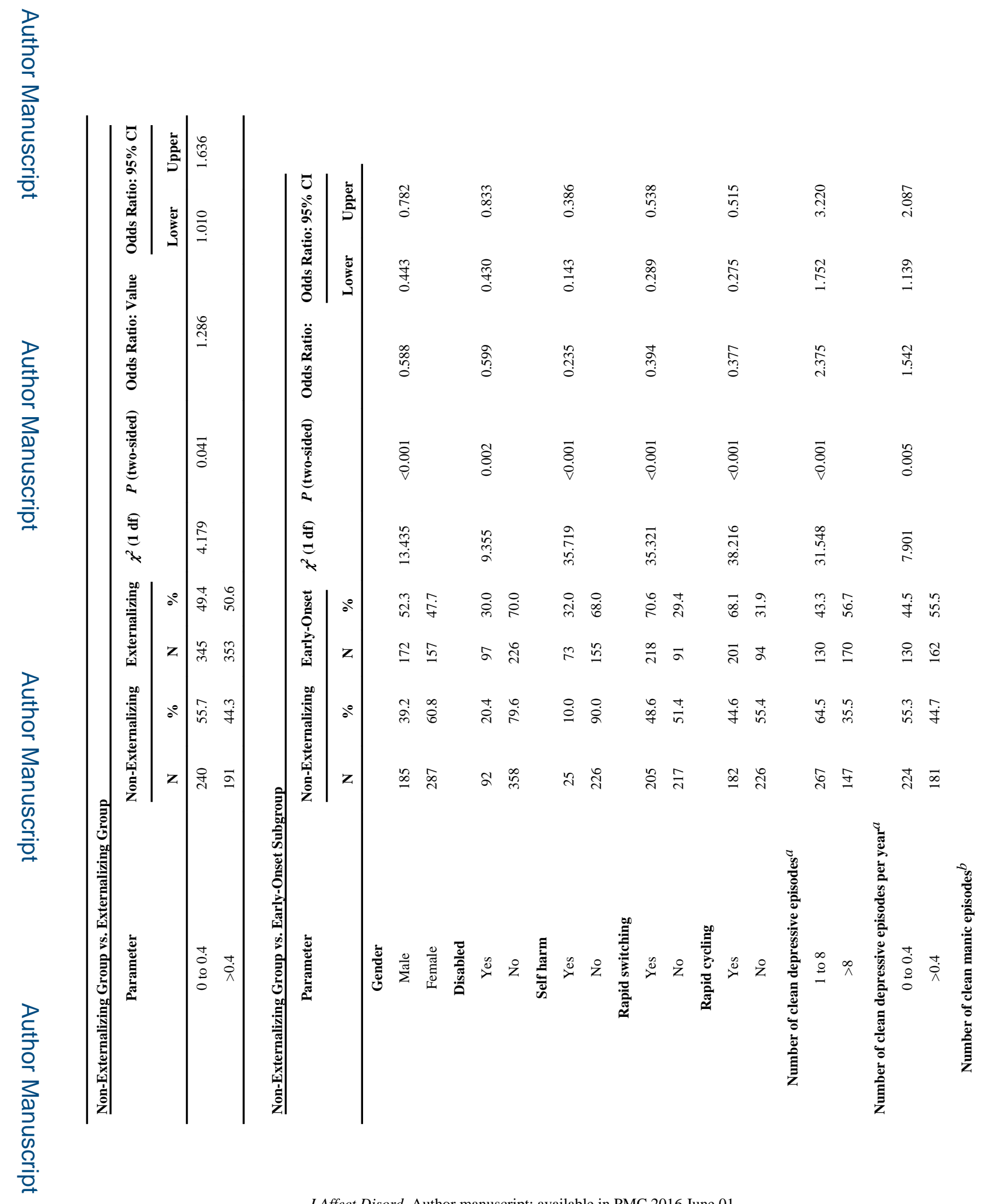

J Affect Disord. Author manuscript; available in PMC 2016 June 01. 


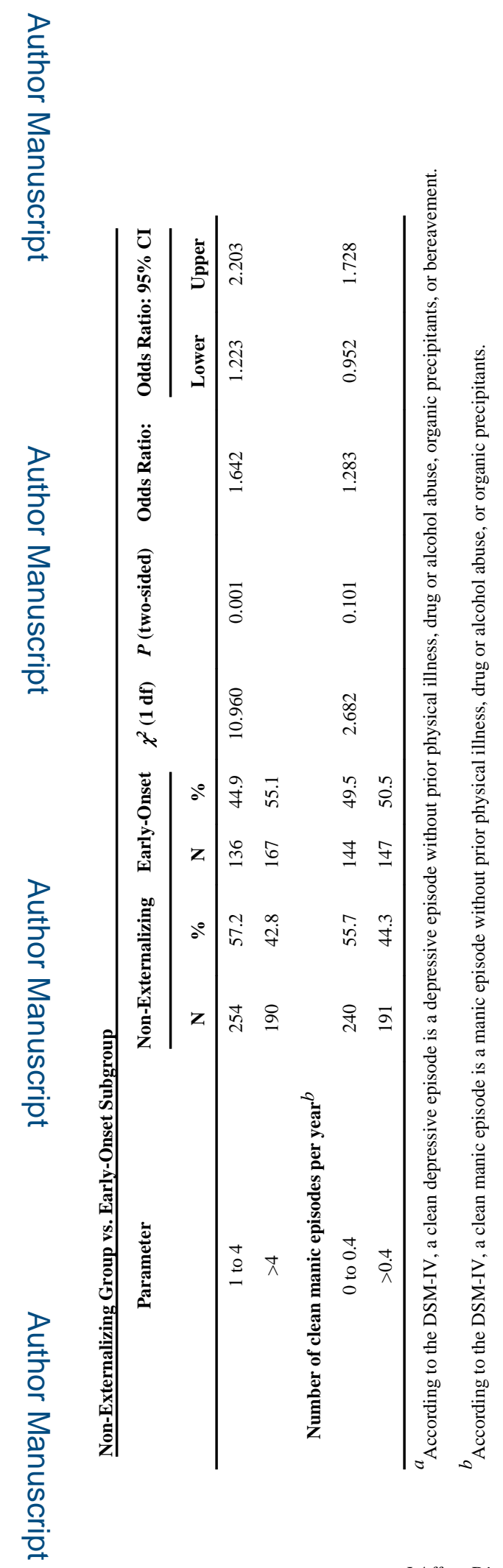

J Affect Disord. Author manuscript; available in PMC 2016 June 01. 


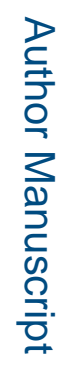

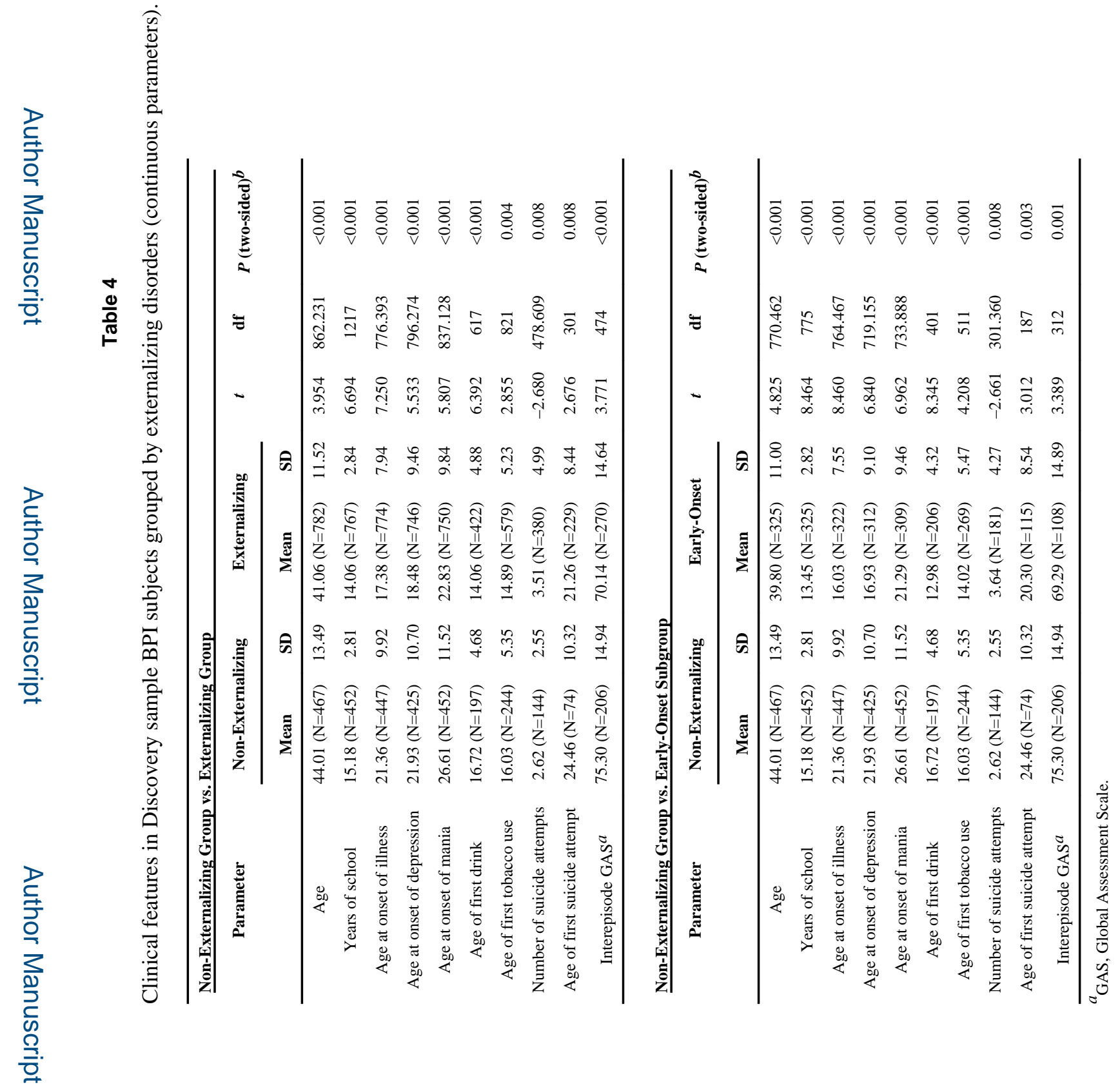

J Affect Disord. Author manuscript; available in PMC 2016 June 01. 


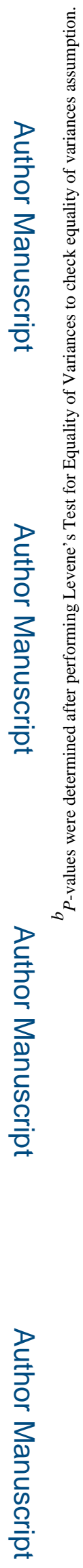

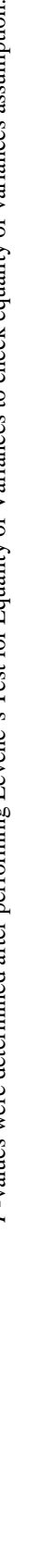




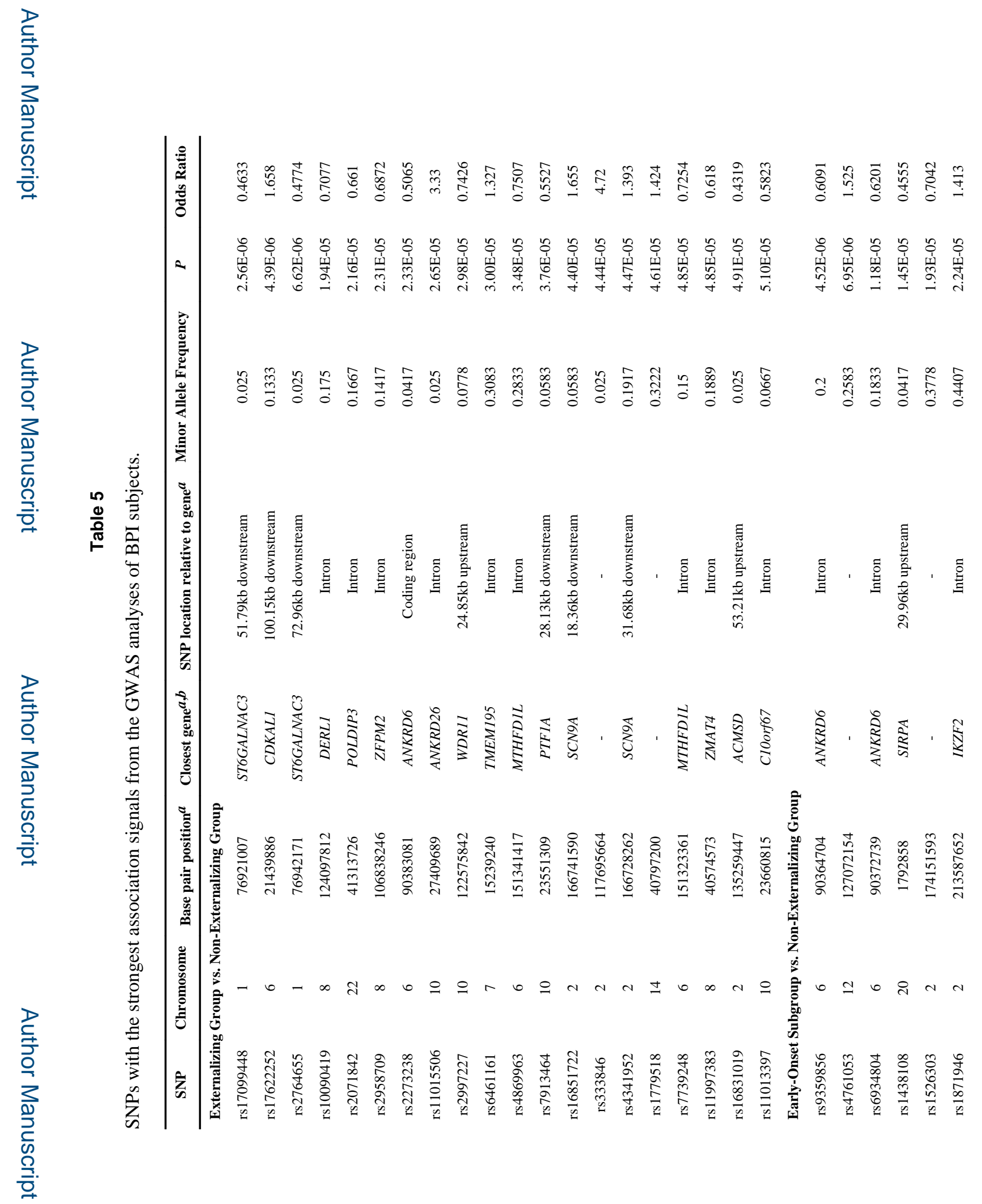

J Affect Disord. Author manuscript; available in PMC 2016 June 01. 


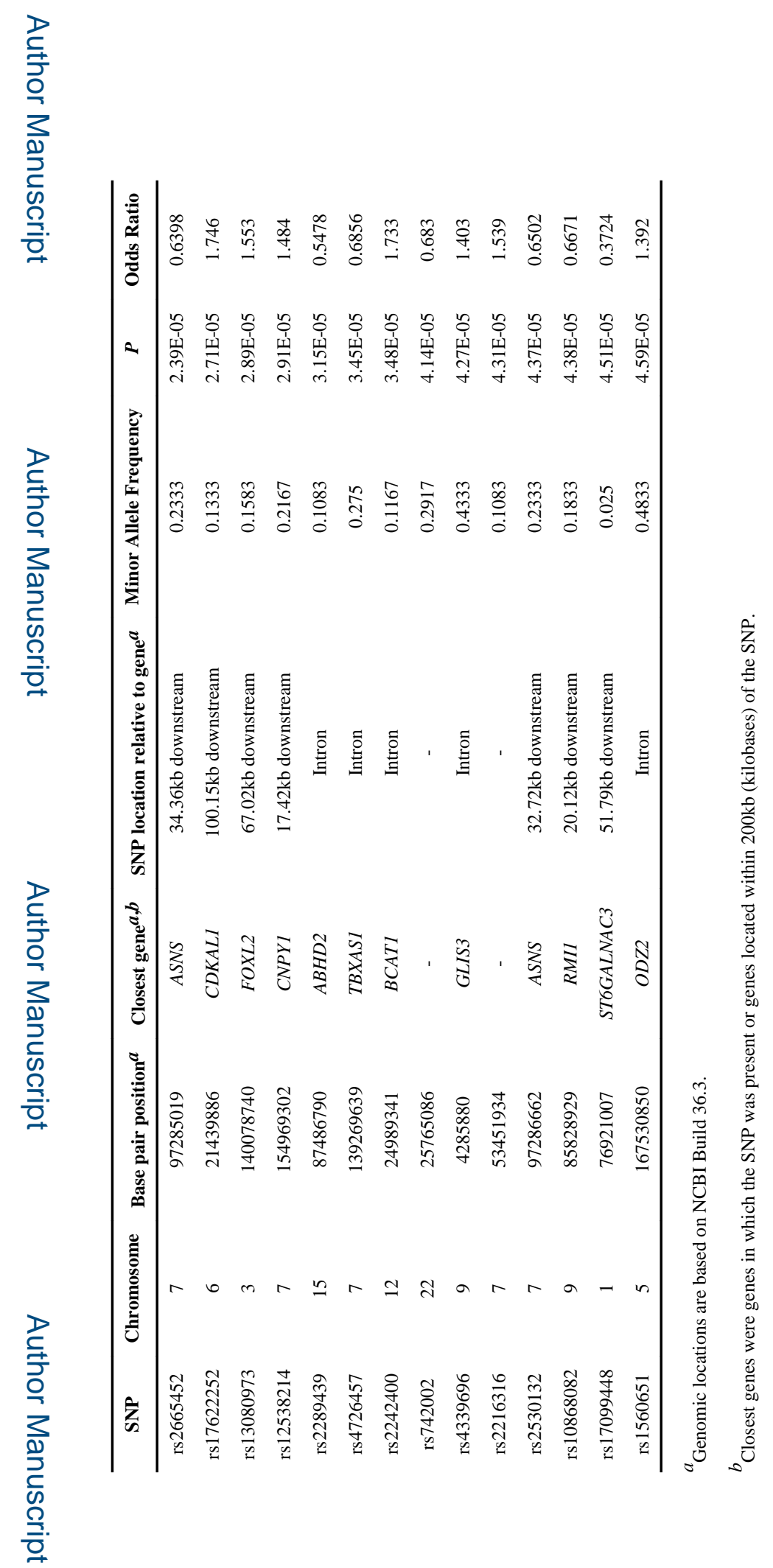

J Affect Disord. Author manuscript; available in PMC 2016 June 01. 